УДК 377:342.6

DOI: https://doi.org/10.32689/2618-0065-2020-2(4)-179-188

Косиця Ольга Олексіївна, доктор юридичних наук, професор кафедри методики професійної освіти та соціально-гуманітарних дисциплін Білоцерківського інституту неперервної професійної освіти ДЗВО «Університет менеджменту освіти» НАПН України, 09108, Київська область, м. Біла Церква, вул. Леваневського, 52/4, (04563) 7-16-07, e-mail: olga.kosytsia@gmail.com, https//orcid.org/0000-0002-5781-780X

Ковальчук Алла Юріївна, доктор юридичних наук, доцент, професор кафедри приватного та публічного права Факультету підприємництва та права Київського університету технологій та дизайну, 01011, Київ, вул. НемировичаДанченка, 2, тел.(067)9158889, e-mail: kovalchukay@i.ua, https//orcid.org/00000003-4807-2436

\title{
КОНЦЕПТУАЛЬНИЙ ЗМІСТ СТАНДАРТИЗАЦЇ̈ ПРОФЕСІЙНОЇ ОСВІТИ В УКРАЇНІ: ПРАВОВИЙ ТА УПРАВЛІНСЬКИЙ АСПЕКТИ
}

Анотація. Об’єктом дослідження виступають суспільні відносини у сфері стандартизації освіти в Україні, предметом є розуміння концептуального змісту стандартизації професійної освіти. Метою статті $\epsilon$ визначення концептуального змісту стандартизації професійної освіти на основі аналізу та узагальнення поглядів науковців різних галузей знань та законотворців на роль та переваги стандартизації освіти на компетентнісно-модульній основі.

Авторами проаналізовано підходи до розуміння сутності стандартизації професійної освіти, іiї переваги та перспективи. Обгрунтовано необхідність приділити належну увагу формуванню ключових компетентностей у здобувачів освіти з урахуванням Рекомендацій Ради Свропейського Союзу від 22 травня 2018 року «Про ключові компетентності для навчання протягом усього життя». Доведено, що концептуальність та системність стандартизації змісту професійної освіти сприяє розвитку партнерських відносин між державою, роботодавцями, закладами освіти та майбутніми працівниками. Узагальнено, що саме поєднання професійних стандартів, стандартів професійної освіти та стандартів оцінювання є тим стрижнем та умовою підготовки кваліфікованого фахівця, який би задовольнив потреби національної економіки, ринку праці і безумовно особисті потреби.

Зроблено висновки, що тенденції до професійного протиборства на ринку праці обумовлюють застосування сучасних освітніх практик для підготовки конкурентоздатного та висококваліфікованого фахівця. Розробка та 
активне застосування стандартів формує компетентності не лише у здобувачів освіти, але й у педагогів. Аналіз вимог роботодавців до майбутнього працівника свідчить все більше про зміщення уваги від знань до умінь і навичок. Ситуація, яка склалась в світі з поширенням пандемії вірусу Covid-19, яскраво продемонструвала як швидко може змінитись світ та звичний уклад життя. Ми не можемо не відзначити, що виховання та навчання здобувачів освіти будь-якого освітнього рівня після такого досвіду повинно зміститись у бік формування особистості, яка усвідомлює, що єдине що $є$ незмінним - це зміни. Стандартизація змісту професійної освіти цьому безумовно сприятиме.

Ключові слова: професійна (професійно-технічна) освіта, стандартизація, ключові компетентності, навчання протягом усього життя, ринок праці.

Kosytsia Olha Oleksiivna, Doctor of Law, Professor of the Department of the Methodology of Vocational Education and Social and Humanitarian Disciplines, Bilotserkva Institute of Continuing Professional Education of the State Institution of Higher Education "UNIVERSITY OF EDUCATION MANAGEMENT" of the National Academy of Pedagogical Sciences of Ukraine, 09108, Kiev region, Bila Tserkva, 52/4 Levanevsky St., (068)7101786, e-mail: olga.kosytsia@gmail.com, https//orcid.org/0000-0002-5781-780X

Kovalchuk Alla Yuriivna, Doctor of Law, Associate Professor, Professor of the Department of Private and Public Law of the Faculty of Entrepreneurship and Law of the Kiev University of Technology and Design, 01011, Kyiv, 2 NemyrovychDanchenko St., tel. (067)9158889, e-mail: kovalchukay@i.ua, https//orcid.org/00000003-4807-2436

\section{CONCEPTUAL CONTENT OF STANDARDIZATION OF VOCATIONAL EDUCATION IN UKRAINE: LEGAL AND MANAGEMENT ASPECTS}

Abstract. The subject of research is public relations in the field of standardization of education in Ukraine, the subject is the understanding of the conceptual content of standardization of vocational education. The purpose of the article is to determine the conceptual content of standardization of vocational education based on the analysis and generalization of the views of scholars of different fields of knowledge and lawmakers on the role and benefits of standardization of education on a competency-modular basis.

The authors analyze the approaches to understanding the essence of standardization of vocational education, its advantages and perspectives. The necessity to pay due attention to the formation of key competences in education recipients is justified, taking into account the recommendations of the Council of the European Union of May 22, 2018 “On Key Competences For Lifelong Learning”. It 
is proved that conceptualization and systematic standardization of the content of vocational education contributes to the development of partnerships between the state, employers, educational institutions and future employees. Generally speaking, it is the combination of professional, vocational education and assessment standards that is the core and condition for the training of a qualified person who would meet the needs of the national economy, the labour market and certainly personal needs.

It is concluded that trends in professional confrontation in the labour market determine the use of modern educational practices to prepare a competitive and highly qualified specialist. The development and active application of standards builds competence not only among educators, but also with teachers. An analysis of employers' requirements for a future employee is increasingly indicative of a shift in focus from knowledge to skills. The situation in the world with the spread of the Covid-19 pandemic has vividly demonstrated how quickly the world and the way of life can change. We cannot but mention that the education and training of those who receive education at any educational level, after such an experience, must shift towards the formation of a person who realizes that the only thing that is unchanged is change. Standardization of the content of vocational education will certainly contribute to this.

Keywords: vocational (vocational-technical) education, standardization, key competences, lifelong learning, labour market.

Постановка проблеми. Концепцією реалізації державної політики у сфері професійної (професійно-технічної) освіти "Сучасна професійна (професійно-технічна) освіта" на період до 2027 року [1] визначено, що основною проблемою, яка потребує розв'язання, є невідповідність підготовки кваліфікованих кадрів потребам особи, національної економіки та суспільства. Одним з проявів цієї проблеми є поряд з іншими - невідповідність змісту освіти та методики викладання вимогам сучасного ринку праці та потребам особи. Методика викладання, зміст освіти як і ринок праці та національна економіка $\epsilon$ комплексними, багатогранними, динамічними системними явищами i процесами, що виключає однозначність та імперативність. Поступове осмислення деяких аспектів та елементів реалізації державної політики у сфері професійної (професійно-технічної) освіти, які представлені Концепцією і не тільки, дозволить усвідомлено та виважено прийти то розуміння та необхідності реформування та удосконалення професійної освіти, основою якої беззаперечно є стандартизація її змісту. Саме стандартизація професійної освіти сприяє розвитку партнерських відносин між державою, роботодавцями, закладами освіти та майбутніми працівниками.

Аналіз останніх досліджень і публікацій. Більше 20 років освітян та роботодавців цікавить тематика стандартизації освіти в Україні. Різним аспектам стандартизації змісту професійної освіти присвячені праці таких 
вчених: Н. М. Ваніна, О. А. Дубасенюк, Н. В. Дупак, Ю. Ф. Зіньковський, А. А. Каленський, С. Г. Кравець, Ю. І. Кравець, Л. І. Короткова, В. І. Луговий, П. Г. Лузан, Л. Б. Лук’янова, С. В. Мельник, Н. Г. Ничкало, С. І. Панцир, Т. М. Пащенко, Л. П. Пуховська, Т. В. Пятничук, Ж. В. Таланова та ін. Але, правовий та адміністративний аспекти даної проблематики залишилися поза увагою, або лише фрагментарно знайшли своє відображення у наукових доробках вчених, і тому потребують окремих наукових розвідок.

Метою статті $\epsilon$ визначення концептуального змісту стандартизації професійної освіти на основі аналізу та узагальнення поглядів науковців різних галузей знань та законотворців на роль та переваги стандартизації освіти на компетентнісно-модульній основі.

Виклад основного матеріалу. Серед основних причин низької якості підготовки кадрів та відсутності в Україні дієвого механізму регулювання системи підготовки кадрів С. І. Мельник та С. В. Панцир виділяють наступні: 1. В Україні так і не розроблено стратегію розвитку на найближчі 15-20 років, чітко не визначено пріоритети в регіонально-галузевому, професійному та функціональному контексті. 2. За період незалежності країни набула розвитку «масовізація» та «комерціалізація» вищої освіти, що призвело до формування «ринку дипломів», згортання прикладних напрямків підготовки та сегментів освіти (професійно-технічної та середньої спеціальної (технікуми, коледжі). 3. Розбалансованість обсягів і напрямів підготовки кадрів у професійному розрізі з потребою в них, що формується на національному та регіональних ринках праці. 4. Низький рівень оновлення в країні професійнокласифікаційної і професійно-кваліфікаційної стандартизації. 5. Відірваність освітніх та освітньо-кваліфікаційних стандартів від вимог Класифікатору професій та Національного класифікатора України ДК 009 «Класифікація видів економічної діяльності» та ін. [2, с. 11-19].

3 метою вирішення проблеми невідповідності підготовки фахівця ринку праці в останні роки активно запроваджується стандартизація змісту професійної освіти. На сьогоднішній день особа має вибір серед більш як 400 професій, які можна здобути в закладах професійної освіти.

Стандартизація професійної освіти - це процедура, що визначає встановлення нормативних вимог кваліфікаційних стандартів до освітніх результатів (компетентностей) випускників закладів професійної освіти, забезпечує перманентне зіставлення навчальних досягнень учнів, студентів 3 цілями їхньої компетентнісно орієнтованої підготовки задля іiі корекції, забезпечує досягнення належних рівнів якості професійної підготовки фахівців у професійних навчальних закладах засобами інноваційності змісту та технологій навчання і сприяє конвертованості рівнів професійної освіти всередині держави та за їі межами [3, с. 4-5].

Стандартизація є ефективним засобом, що стимулює властиві освіті якості: здатність до саморозвитку i самовдосконалення. Зміст освіти, 
виступаючи оптимальним об’єктом стандартизації, є тим унікальним основним стрижнем, що досить міцно й у той же час досить гнучко поєднує всі рівні системи освіти, визначає їхню послідовність і наступність [4]. Стандарти в професійній освіті і навчанні - це своєрідний зв’язок між системою освіти, 3 одного боку, і ринком праці та промисловістю - 3 іншого. Зв'язок між стандартами професійної освіти і навчання в секторі освіти, включаючи загальну і вищу освіту, та ринком праці постійно змінюється, в залежності від політики країни в цій галузі та їі правової основи [5, с. 6].

Правовою основою стандартизації професійної освіти є закони України («Про освіту» (2017), «Про професійно-технічну освіту» (1998), «Про стандартизацію» (2014), «Про фахову передвищу освіту» (2019), «Про професійний розвиток працівників» (2012) та ін.), постанови та розпорядження Кабінету міністрів України («Про затвердження Національної рамки кваліфікацій» від 23.11.2011 p. № 1341; «Про затвердження Порядку розроблення та затвердження професійних стандартів» від 31.05.2017 р. № 373; «Про затвердження Плану заходів із впровадження Національної рамки кваліфікацій на 2016-2020 роки» від 14.12.2016 р. № 1077; «Про затвердження Державного переліку професій 3 підготовки кваліфікованих робітників у професійно-технічних навчальних закладах» від 11.09.2007 p. № 1117, «Про схвалення Концепції реалізації державної політики у сфері професійної (професійно-технічної) освіти “Сучасна професійна (професійно-технічна) освіта"» на період до 2027 року), інші нормативно-правові акти (наказ Міністерства соціальної політики України від 22.01.2018 р. № 74 «Про затвердження Методики розроблення професійних стандартів», наказ Міністерства освіти i науки України від 15.05.2013 p. № 511 «Про затвердження методики розроблення державних стандартів професійнотехнічної освіти 3 конкретних робітничих професій»; наказ Міністерства освіти і науки, молоді та спорту України від 26.04.2012 p. № 522 «Про затвердження Методичних рекомендацій щодо розроблення Державних стандартів професійно-технічної освіти 3 конкретних професій на основі компетентнісного підходу»).

Реформування системи забезпечення якості професійної (професійнотехнічної) освіти передбачає: формування внутрішньої системи забезпечення якості освіти та системи зовнішнього забезпечення якості освіти; розроблення нових стандартів професійної (професійно-технічної) освіти на базі професійних стандартів, які грунтуються на компетентнісному та особистісноорієнтованому підходах до навчання; формування мережі кваліфікаційних центрів, основними функціями яких $є$ оцінювання i визнання результатів навчання, присвоєння та/або підтвердження відповідних професійних кваліфікацій; забезпечення стимулювання професійного зростання педагогічних працівників, а також залучення до освітнього процесу висококваліфікованих працівників виробництва та сфери послуг [1]. 
У професійній освіті виділено необхідність формування загально професійних, професійних та ключових компетентностей. Метою стандартизації професійної освіти на основі компетентісно-модульного підходу є формування у майбутнього кваліфікованого працівника необхідних компетентностей, однаково важливих для соціалізації, професійного розвитку та самоідентифікації.

C. В. Мельник та С. І. Панцир справедливо відмічають, що однією 3 найбільш перспективних за останнє десятиліття в СС і багатьох інших країнах стала методика підготовки кадрів через результати навчання, заснована на компетентнісному підході. Вона направлена на визнання кваліфікацій різних типів, отриманих через різні форми освіти та навчання (формальна та неформальна освіта, самостійне (спонтанне, інформальне) навчання) в чіткому, прозорому й підтверджуваному процесі оцінювання наявних знань, умінь, навичок, здатності застосовувати їх на практиці, як того вимагають професійні стандарти, розроблені представниками ринку праці [2, с. 7]. Визначено, що стандартизація професійної освіти має бути конструктом чотирьох взаємопов'язаних, послідовних етапів досягнення належних рівнів якості підготовки фахівців (розроблення та затвердження кваліфікаційних стандартів професійної освіти - професійного, освітнього, стандарту оцінювання; проектування змісту компетентнісно орієнтованого змісту освіти - освітніх програм, навчальних планів, навчальних програм дисциплін та ін.; обгрунтування та впровадження педагогічних технологій, що забезпечують гарантоване досягнення результатів компетентнісного навчання; оцінювання компетентнісних досягнень учнів, студентів, випускників засобами об'єктивних, валідних методик) [6, с. 35]. Отже, саме поєднання професійних стандартів, стандартів професійної освіти та стандартів оцінювання є тим стрижнем та умовою підготовки кваліфікованого фахівця, який би задовольнив потреби національної економіки, ринку праці і безумовно особисті потреби.

В залежності від професії змінюються не лише загально-професійні та професійні компетентності, але й ключові. Для професії, наприклад, «пекаря» стандартом професійної освіти встановлено такі компетентності як: усвідомлення важливості свого трудового внеску в досягнення колективу; оперативність в прийнятті правильних рішень у позаштатних ситуаціях під час роботи; здатність відповідально ставитися до професійної діяльності; здатність діяти в нестандартних ситуаціях; здатність працювати в команді; дотримання професійної етики; здатність запобігати конфліктних ситуацій та ін. Відповідно для професії «адміністратор» ключовою буде компетентність здатність вирішувати конфліктні ситуації, організовувати роботу в команді тощо.

Академіки Н. Г. Ничкало i Ю. Ф. Зіньковський зауважують, що в стандартах цього покоління «принципово важливим $\epsilon$ питання співвідношення природничо-математичної, гуманітарної, загальнотехнічної, професійно- 
теоретичної, професійно-практичної, фізичної підготовки..., важливо постійно приділяти увагу загальноосвітній, культурологічній підготовці спеціаліста, без якої неможливо досягти високого рівня професійної культури» [7, с. 34]. Погоджуючись 3 шановними академіками, слід додати, що всі компетентності в першу чергу формуються задля успішної соціалізації, що дасть змогу професійній реалізації та/або подальшому навчанню.

Рекомендаціями Ради Європейського Союзу від 22 травня 2018 року «Про ключові компетентності для навчання протягом усього життя» [8] передбачено, що ключовими компетентностями $є$ ті, які необхідні всім людям для підвищення особистого потенціалу і розвитку, розширення можливостей працевлаштування, соціальної інтеграції та активного громадянства. Такі компетентності розвиваються в процесі навчання протягом усього життя, починаючи 3 раннього дитинства шляхом формального, неформального та інформального навчання. Такі навички, як критичне мислення, аналітичне мислення, вирішення проблем, творчість, робота в команді, вміння спілкування та проводити переговори, прийняття рішень, саморегуляція, стійкість, емпатія, участь, повага до різноманітності, враховуються у всіх ключових компетентностях [9]. Отже рекомендаціями Ради СС визначено такі ключові компетентності: 1. Грамотність (Literacy competence), 2. Мовна компетентність (Languages competence), 3. Математична компетентність та компетентність у науках, технологіях та інженерії (Mathematical competence and competence in science, technology and engineering), 4. Цифрова компетентність (Digital competence). 5. Особиста, соціальна та навчальна компетентність (Personal, social and learning competence). 6. Громадянська компетентність (Civic competence). 7. Підприємницька компетентність (Entrepreneurship competence). 8. Компетентність культурної обізнаності та самовираження (Cultural awareness and expression competence).

Вказана Рекомендація замінює Рекомендацію Європейського Парламенту та Ради Свропи від 18 грудня 2006 р. «Про основні компетенції для навчання протягом усього життя», якою також було встановлено вісім основних компетенцій: 1) Спілкування рідною мовою; 2) Спілкування іноземними мовами; 3) Знання математики та загальні знання у сфері науки і техніки; 4) Навички роботи з цифровими носіями; 5) Навчання заради здобуття знань; 6) Соціальні та громадянські навички; 7) Ініціативність та практичність; 8) Обізнаність та самовираження у сфері культури [10].

Перевагами нових стандартів професійної освіти на основі компетентнісно-модульного підходу для закладів професійної освіти є: швидке реагування на зміни у техніці, технологіях, змісті діяльності сфери праці; встановлення взаємозацікавлених та взаємовигідних стосунків з потенційними роботодавцями; врегулювання процесу працевлаштування випускників; набуття учнями професійної кваліфікації та компетентності для роботи i трудової діяльності; упровадження механізму зовнішнього оцінювання рівня 
професійної кваліфікації випускника. Для роботодавців - це можливість: установлення варіативності та різностроковості освітнього процесу; упровадження дієвого впливу на формування змісту та організацію професійного навчання; отримання компетентних фахівців, які точно відповідають вимогам підприємства; підвищення продуктивності і якості послуг і продукції; здійснення контролю за оцінюванням результатів підготовки робітника [5, с. 65-66].

Фахівці з розвитку бізнесу та працевлаштування, для яких вивчення попиту та пропозиції на ринку праці $є$ основною сферою дослідження та професійної діяльності, підсумовують, що здобувач освіти навчаючись, не лише здобуває знання, але й вчиться вчитися. I це в процесі навчання вже стає чи не найголовнішим. Адже в стрімких умовах автоматизації робочих місць велика вірогідність, що кожна людина повинна бути готовою до змін, а саме перевчитись, перекваліфікуватись, адаптуватись, попрощатись зі здобутою навичкою та опанувати нову. Для цього і потрібно більшою мірою звертати увагу на формування у здобувачів освіти ключових компетентностей. Окрему увагу фахівці звертають на здатність спостерігати за трендами та усвідомлення своєї цінності, самоідентифікації.

Висновки. Стандартизація в освіті, зокрема в професійній, є наслідком та причиною трансформації соціального та економічного середовища в Україні та світі. Світ з розвитком інформаційних технологій та активного застосування штучного інтелекту швидко змінюється. Тенденції до професійного протиборства на ринку праці обумовлюють застосування сучасних освітніх практик для підготовки конкурентоздатного та висококваліфікованого фахівця. Здобувачі освіти повинні буди пристосовані до змін та очікувань, які висувають до них роботодавці. Розробка та активне застосування стандартів формує компетентності не лише у здобувачів освіти, але й у педагогів. Аналіз вимог роботодавців до майбутнього працівника свідчить все більше про зміщення уваги від знань до умінь і навичок. Ситуація, яка склалась в світі 3 поширенням пандемії вірусу Covid-19 яскраво продемонструвала як швидко може змінитись світ та звичний уклад життя. Ми не можемо не відзначити, що виховання та навчання здобувачів освіти будь-якого освітнього рівня після такого досвіду повинно зміститись у бік формування особистості, яка усвідомлює, що єдине що є незмінним - це зміни. Стандартизація змісту професійної освіти цьому безумовно сприятиме.

\section{Jimepamypa:}

1. Про схвалення Концепції реалізації державної політики у сфері професійної (професійно-технічної) освіти «Сучасна професійна (професійно-технічна) освіта» на період до 2027 року: Розпорядження Кабінету міністрів України від 12 червня 2019 р. № 419-p. URL : https://zakon.rada.gov.ua/laws/show/419-2019-\%D1\%80

2. Мельник С., Панцир С. Як в Україні створити сучасну систему кваліфікацій? К.: Європейський інформаційно-дослідницький центр, 2016. 64 с.

3. Стандартизація професійної освіти: теорія i практика: монографія / 
А. А. Каленський, П. Г. Лузан, Н. М. Ваніна, Т. М. Пащенко, С. Г. Кравець, Т. В. Пятничук. За наук. ред. А. А. Каленського. Житомир: «Полісся», 2018. 256 с.

4. Дупак Н. В. Особливості реалізації системного підходу до стандартизації професійної освіти / Професійна педагогічна освіта: системні дослідження : монографія за ред. О. А. Дубасенюк. Житомир: Вид-во ЖДУ ім. І. Франка, 2015. С. 109-124.

5. Дієвказ розробникам стандартів професійної (професійно-технічної) освіти створених на компетентнісно-модульній основі (проект). Міністерство освіти і науки України, Інститут модернізації змісту освіти. Київ. 2018. 68 с.

6. Лузан П. Г., Пащенко Т. М., Ваніна Н. М., Колісник Н. В. Стандартизація професійної освіти на основі компетентнісного підходу. Journal «ScienceRise: Pedagogical Education». №5(25). 2018. С. 32-35.

7. Державні стандарти професійної освіти: теорія і методика: монографія / за ред. Н.Г. Ничкало. Хмельницький: ТУП, 2002. 334 с

8. ANNEX to the Proposal for a Council Recommendation on Key Competences for Lifelong Learning. Brussels, 2018. URL : https://eur-lex.europa.eu/legalcontent/EN/TXT/PDF/?uri=CELEX:32018H0604(01)\&from=EN

9. Освіта на основі життєвих навичок: Адвокаційний модуль для керівних кадрів. URL : http://dlse.multycourse.com.ua/ua/page/15/53

10. Рекомендація 2006/962/ЄС Європейського Парламенту та Ради (ЄС) «Про основні компетенції для навчання протягом усього життя» від 18 грудня 2006 року. URL : https://zakon.rada.gov.ua/laws/show/994_975

\section{References:}

1. Rozporiadzhennia Kabinetu ministriv Ukrainy "Pro skhvalennia Kontseptsii realizatsii derzhavnoi polityky u sferi profesiinoi (profesiino-tekhnichnoi) osvity «Suchasna profesiina (profesiino-tekhnichna) osvita» na period do 2027 roku” : vid 12 chervnia 2019 r., № 419-r [Order of the Cabinet of Ministers of Ukraine “On approval of the Concept of realization of state policy in the sphere of vocational (vocational-technical) education "Modern vocational (vocational-technical) education" for the period up to 2027" from June 12, 2019, № 419-p]. (n.d.). zakon.rada.gov.ua. Retrieved from https://zakon.rada.gov.ua/laws/show/419-2019-\%D1\%80 [in Ukrainian].

2. Melnyk, S., Pantsyr, S. (2016). Yak v Ukraini stvoryty suchasnu systemu kvalifikatsii? [How to create a modern qualification system in Ukraine?]. Kyiv: Yevropeiskyi informatsiino-doslidnytskyi tsentr [in Ukrainian].

3. Kalenskyi, A.A., Luzan, P.H., Vanina, N.M., Pashchenko, T.M., Kravets, S.H., Piatnychuk, T.V. (2018). Standartyzatsiia profesiinoi osvity: teoriia i praktyka [Standardization of Vocational Education: Theory and Practice]. Zhytomyr: «Polissia» [in Ukrainian].

4. Dupak, N.V. (2015). Osoblyvosti realizatsii systemnoho pidkhodu do standartyzatsii profesiinoi osvity [Features of realization of systematic approach to standardization of vocational education]. Profesiina pedahohichna osvita: systemni doslidzhennia - Professional pedagogical education: system studies. (pp. 109-124). O. A. Dubaseniuk (Eds.). Zhytomyr: Vyd-vo ZhDU im. I. Franka [in Ukrainian].

5. Diievkaz rozrobnykam standartiv profesiinoi (profesiino-tekhnichnoi) osvity stvorenykh na kompetentnisno-modulnii osnovi (proekt) [Diavkaz to developers of standards of vocational (vocational-technical) education created on a competency-modular basis (project)]. (2018). Kyiv [in Ukrainian]. 
6. Luzan, P.H., Pashchenko, T.M., Vanina, N.M., Kolisnyk, N.V. (2018). Standartyzatsiia profesiinoi osvity na osnovi kompetentnisnoho pidkhodu [Standardization of vocational education on the basis of competence approach]. Journal «ScienceRise: Pedagogical Education», 5(25), 32-35 [in Ukrainian].

7. Nychkalo, N.H. (Eds.). (2002). Derzhavni standarty profesiinoi osvity: teoriia $i$ metodyka [State standards of professional education: theory and methodology]. Khmelnytskyi: TUP [in Ukrainian].

8. ANNEX to the Proposal for a Council Recommendation on Key Competences for Lifelong Learning. (2018). eur-lex.europa.eu. Retrieved from https://eur-lex.europa.eu/legalcontent/EN/TXT/PDF/?uri=CELEX:32018H0604(01)\&from=EN [in English].

9. Rozdil 1. Nova paradyhma osvity u hlobalnomu sviti. 1.2. Kliuchovi kompetentnosti dlia navchannia protiahom zhyttia [Chapter 1. The New Paradigm of Education in the Global World. 1.2. Key competences for lifelong learning]. dlse.multycourse.com.ua. Retrieved from http://dlse.multycourse.com.ua/ua/page/15/53 [in Ukrainian].

10. Rekomendatsiia 2006/962/YeS Yevropeiskoho Parlamentu ta Rady (YeS) «Pro osnovni kompetentsii dlia navchannia protiahom usoho zhyttia» : vid 18 hrudnia 2006 roku [Recommendation 2006/962 / EC of the European Parliament and of the Council (EU) on core competences for lifelong learning from 18 December 2006]. zakon.rada.gov.ua. Retrieved from https://zakon.rada.gov.ua/laws/show/994_975 [in Ukrainian]. 